\title{
Exposure to phenanthrene and depuration: Changes on gene transcription, enzymatic activity and lipid peroxidation in gill of scallops Nodipecten nodosus
}

\author{
Rômi S. Piazza ${ }^{a}$, Rafael Trevisan ${ }^{a}$, Fabrício Flores-Nunes ${ }^{a}$, Guilherme Toledo-Silva ${ }^{a}$, \\ Nestor Wendt ${ }^{a}$, Jacó J. Mattos ${ }^{b}$, Daína Lima ${ }^{a}$, Satie Taniguchi ${ }^{c}$, Silvio Tarou Sasaki ${ }^{c}$, \\ Álvaro C.P. Mello ${ }^{a}$, Flávia L. Zacchi ${ }^{a}$, Miguel A.S. Serrano ${ }^{\mathrm{a}}$, Carlos H.A.M. Gomes $^{\mathrm{d}}$, \\ Márcia C. Bícego ${ }^{c}$, Eduardo A.de Almeida ${ }^{e}$, Afonso C.D. Bainy ${ }^{\mathrm{a}, *}$ \\ a Laboratory of Biomarkers of Aquatic Contamination and Immunochemistry, Department of Biochemistry, Federal University of Santa Catarina, UFSC, \\ Florianópolis, SC, Brazil \\ ${ }^{\mathrm{b}}$ Aquaculture Pathology Research Center - NEPAQ Federal University of Santa Catarina, Florianópolis, SC, Brazil \\ ${ }^{c}$ Laboratory of Marine Organic Chemistry, Oceanographic Institute, University of São Paulo, São Paulo, Brazil \\ ${ }^{\mathrm{d}}$ Laboratory of Marine Mollusks (LMM), Department of Aquaculture, Center of Agricultural Science, Federal University of Santa Catarina, Florianópolis, SC, \\ Brazil \\ e Department of Chemical and Environmental Sciences, IBILCE, UNESP, São José do Rio Preto, SP, Brazil
}

\section{A R T I C L E I N F O}

\section{Article history:}

Received 5 March 2016

Received in revised form 24 May 2016

Accepted 25 May 2016

Available online 26 May 2016

\section{Keywords:}

Phenanthrene

Biotransformation

Scallops

Nodipecten nodosus

Depuration

Mollusks

\begin{abstract}
A B S T R A C T
Understanding the mechanism of phenanthrene (PHE) biotransformation and related cellular responses in bivalves can be an important tool to elucidate the risks of polycyclic aromatic hydrocarbons (PAHs) to aquatic organisms. In the present study it was analyzed the transcriptional levels of 13 biotransformation genes related to cytochrome P450 (CYP), glutathione S-transferase (GST), sulfotransferase (SULT), flavin-containing monooxygenase and fatty acid-binding proteins by qPCR in gill of scallops Nodipecten nodosus exposed for 24 or $96 \mathrm{~h}$ to 50 or $200 \mu \mathrm{g} \mathrm{L}^{-1} \mathrm{PHE}$ (equivalent to 0.28 and $1.12 \mu \mathrm{M}$, respectively), followed by depuration in clean water for $96 \mathrm{~h}$ (DEP). Likewise, it was quantified the activity of catalase (CAT), glutathione peroxidase (GPX), superoxide dismutase (SOD), glutathione reductase (GR), glucose 6phosphate dehydrogenase (G6PDH), GST and levels of lipid peroxidation. Increased transcriptional levels of CYP2UI-like, CYP2D20-like, CYP3A11-like, GSTomega-like, SULT1B1-like genes were detected in organisms exposed to PHE for 24 or $96 \mathrm{~h}$. In parallel, GR and GPX activities increased after $96 \mathrm{~h}$ exposure to $200 \mu \mathrm{g} \mathrm{L}^{-1}$ PHE and G6PDH activity increased after $24 \mathrm{~h}$ exposure to $50 \mu \mathrm{g} \mathrm{L}^{-1} \mathrm{PHE}$. This enhancement of antioxidant and phase I and II biotransformation systems may be related to the 2.7 and 12.5 fold increases in PHE bioaccumulation after $96 \mathrm{~h}$ exposure to 50 and $200 \mu \mathrm{g} \mathrm{L}^{-1}$ PHE, respectively. Interestingly, DEP caused reestablishment of GPX and GR activity, as well as to the transcript levels of all upregulated biotransformation genes (except for SULT1B1-like). Bioaccumulated PHE levels decreased 2.5-2.9 fold after depuration, although some biochemical and molecular modifications were still present. Lipid peroxidation levels remained lower in animals exposed to $200 \mu \mathrm{g} \mathrm{L}^{-1}$ PHE for $24 \mathrm{~h}$ and DEP. These data indicate that $N$. nodosus is able to induce an antioxidant and biotransformation-related response to PHE exposure, counteracting its toxicity, and DEP can be an effective protocol for bivalve depuration after PHE exposure.
\end{abstract} (c) 2016 Elsevier B.V. All rights reserved.

\section{Introduction}

Aquatic environment is considered quite vulnerable to anthropogenic pressure as a final recipient of a variety of pollutants.

\footnotetext{
* Corresponding author.

E-mail address: afonso.bainy@ufsc.br (A.C.D. Bainy).
}

Oil spills are among the major factors causing marine contamination, as about 87 million barrels of oil are globally produced every day. Spilled oil consists primarily of aliphatic/aromatic hydrocarbons and polar compounds, and leakage may occur during transportation and pyrolytic processes plus domestic and industrial wastewater discharges (Martins et al., 2013; Wei et al., 2015). Polycyclic aromatic hydrocarbons (PAH), main components of crude oil, are ubiquitously found in the marine environment. Phenanthrene 
(PHE) is a low molecular weight PAH with three fused benzene (aromatic) rings and is a representative component of PAH compounds present in the marine ecosystem (De Luca-Abbott et al., 2005; Schäfer and Köhler, 2009).

PHE is often used as a model for the study on PAHs metabolism, it is readily bioavailable (Hannam et al., 2010a; Wootton et al., 2003) and the smallest PAH to have a bay and a K-region that represent a highly reactive region where the main carcinogenic species can be formed (Zhang et al., 2014). Owing to its high lipophilic nature, PHE can easily penetrate biological membranes; bioaccumulation tends to be fast and, as a global persistent organic pollutant, it may raise health concerns even several decades after exposure (Jin et al., 2015; Noh et al., 2015; Xiu et al., 2015). PHE has been included in "Priority Pollutants" list by the United States Environment Protection Agency (US, EPA), and although not carcinogenic and mutagenic, it has been shown to be toxic to several marine animals (Zhang et al., 2014). Studies have shown that PHE induces oxidative stress, immunosuppression and genotoxicity in mollusks, besides molecular alterations at transcriptional gene levels (Einsporn and Koehler, 2008; Hannam et al., 2010a). PAHs toxicity is associated to its cellular detoxification mechanisms, with some of the produced metabolites being highly reactive to DNA to adduct formation (Akcha et al., 2000). Different mechanisms of PHE toxicity have been proposed, but the most convincing evidence is related to its metabolic activation by members of the cytochrome P450 (CYP) superfamily during the phase I biotransformation (Schlenk, 1998; Zanette et al., 2008). Phase I by-products can conjugate to endogenous substrates during the phase II biotransformation, catalyzed by enzymes like glutathione-S-transferase (GSTs) and sulfotransferases (SULTs), leading to the formation of hydrophilic conjugates for further excretion.

PAH biotransformation can lead to the production of reactive oxygen species (ROS), which may oxidizes proteins, DNA and cause lipid peroxidation (Grintzalis et al., 2012; Noh et al., 2015). Consequently, a complex array of antioxidant systems acts preventing cumulative oxidative damage by neutralizing excess of ROS (Halliwell and Gutteridge, 1985). In addition, animals subjected to stress have an increased energy demand, mobilizing metabolic fuel (e.g. fatty acids) for survival. Fatty acid-binding proteins (FABP) are highly active in fatty acid metabolism, participate in lipid uptake, transport and homeostasis (Bayır et al., 2015; Travers et al., 2010).

The use of bivalves in pollution-related studies has increased over the last decade, especially regarding PAH, crude oil, pesticide and metal toxicity (Hannam et al., 2010a). The scallop Nodipecten nodosus is considered a good sentinel bivalve, with wide geographic distribution (from USA to Brazil), because of its susceptibility to the toxic effects of a large number of contaminants, besides their important economic value (Cranford, 2006; Freites et al., 2010). Considering its filter-feeding behavior and its capacity to bioaccumulate xenobiotics, the legislation in some countries request the use of scallops depuration protocols in order to minimize the risk of human contamination. In this context, it is clear that depuration procedures may help to increase bivalve health and production. It can be an effective tool (at different extents) in removing many thermo-tolerant bacteria, viral contaminants, vibrios, biotoxins, trace metals or organic chemicals (FAO, 2008).

Encompassing these questionings and in order to get answers to clarify the mechanisms of PHE biotransformation, the aim of this study was to investigate the changes in activities of biotransformation and antioxidants enzymes, lipid peroxidation levels, as well as the levels of transcriptional genes with important role in the biotransformation mechanisms of PHAs in gill of N. nodosus. A depuration protocol was developed and tested in order to estimate the applicability of this technique to allow decontamination of animals exposed to $\mathrm{PAH}$.

\section{Materials and methods}

\subsection{Scallops and exposure conditions}

Scallops $N$. nodosus of similar shell length $(6.0-8.0 \mathrm{~cm})$ were collected from a scallop farm at Enseada do Brito beach, (SCBrazil). After collection, animals were cleaned and transported to the Marine Mollusks Laboratory (LMM, UFSC, Brazil) for an acclimation period of 7 days before the exposure. Animals were placed in aerated fiberglass tanks with filtered seawater $(0.45 \mu \mathrm{m})$ on a net support to avoid contact with the bottom. A renewal water system (1.4 L min ${ }^{-1}, 18^{\circ} \mathrm{C}$ and $\left.30 \mathrm{PSU}\right)$ was applied and scallops were fed with a maintenance diet (a mix of Isochrysis galbana and Chaetoceros muelleri).

PHE (P1140-9, 98\% purity, Sigma - Aldrich) was dissolved in dimethylsulfoxide (DMSO) and added to filtered seawater to achieve final nominal PHE concentrations of 50 and $200 \mu \mathrm{g} \mathrm{L}^{-1}$, equivalent to 0.28 and $1.12 \mu \mathrm{M}$, and a final maximum DMSO concentration of $0.01 \%(\mathrm{v} / \mathrm{v})$. PHE concentrations were chosen based on previous data reported in studies with bivalves (Hannam et al., 2010a, 2010b; Wootton et al., 2003; Zhang et al., 2014). Scallops were allocated in three static tanks with the same water conditions after acclimation period (control group, 50 and $200 \mu \mathrm{g} \mathrm{L}^{-1} \mathrm{PHE}$ ), each one maintaining the ratio of $8 \mathrm{~L}$ of water per animal. Seawater was renewed (100\%) and spiked with PHE stock solution every $24 \mathrm{~h}$ to maintain water quality and reestablish PHE levels during $96 \mathrm{~h}$ of exposure. Control group was subjected to the same conditions, except for the addition of $0.01 \%$ DMSO instead PHE. Animals were not fed during this period in order to prevent potential bioaccumulation of PHE by food. After $24 \mathrm{~h}$ and $96 \mathrm{~h}, 10$ scallops from each group were collected, the gill was immediately excised, frozen in liquid nitrogen and stored at $-80^{\circ} \mathrm{C}$ for biochemical and molecular assays.

After $96 \mathrm{~h}$ of PHE exposure, a depuration system was established (DEP). Animals were fed with the maintenance diet and seawater was renewed once a day (100\%). DMSO and PHE were not added to the tanks in this period. After DEP, 10 scallops per group were dissected and the gill was stored as described.

\subsection{Tissue PHE concentration}

To confirm PHE bioaccumulation and the detoxification capacity of scallops, whole soft tissue samples (pools of 10 individuals per group after $96 \mathrm{~h}$ and DEP periods) were analyzed for PHE by the method of McLeod et al. (1985) with minor modification. Briefly, samples were frozen-dried, homogenized and $1 \mathrm{~g}$ was Soxhlet-extracted with a $50 \%$ mixture of residue grade $n$-hexane and dichloromethane for $8 \mathrm{~h}$. Before extraction, $\mathrm{d} 8$-naphthalene, d10-acenaphthene, d10-phenanthrene, d12-chrysene and d12perylene were added as surrogates in the blank, samples and standard reference material (SRM 2974a - Organics in freeze-dried mussels tissue Mytilus edulis) from National Institute of Standards and Trends (NIST). Hydrocarbon extracts were cleaned up by silica gel-alumina column chromatography and were quantitatively analyzed by an Agilent 6890 gas chromatograph coupled to a $5973 \mathrm{~N}$ mass spectrometer (GC/MS) in a selected ion mode (SIM). A $25 \mathrm{~m}$, $0.32 \mathrm{~mm}$ i.d., $0.25-\mu \mathrm{m}$ HP5MS film, capillary column from Agilent was temperature programmed from $40^{\circ} \mathrm{C}$ to $60^{\circ} \mathrm{C}$ at $20^{\circ} \mathrm{C} \mathrm{min}^{-1}$ and $60^{\circ} \mathrm{C}$ to $300 \circ \mathrm{C}$ at $4{ }^{\circ} \mathrm{C} \mathrm{min}^{-1}$, and held at $300^{\circ} \mathrm{C}$ for $10 \mathrm{~min}$ in GC/MS. Phenanthrene was quantitatively analyzed based on reten- 
Table 1

Primer sequences used for the qPCR for the amplification of each target and endogenous reference gene with putative gene name and amplicon size (bp).

\begin{tabular}{|c|c|c|}
\hline Gene name & Primer sequence $5^{\prime}-3^{\prime}$ & Amplicon size (bp) \\
\hline \multicolumn{3}{|l|}{-} \\
\hline \multirow[t]{2}{*}{ 40s-like } & F - GCTTAGATGTGCTTGCCCTGAAAGAG & 131 \\
\hline & R - GTGGACACCATCAGCTTTGCGTTTA & \\
\hline \multirow{2}{*}{ Ef1-like } & F - CAAGGTCAGAGTATTGCCCATCAC & 96 \\
\hline & $\mathrm{R}$ - CGGTCAACACAGGATAAGGATGTC & \\
\hline \multirow[t]{2}{*}{ CYP1A1-like } & F - AAGGAAAGAAGCCGAGGAGGAAGATG & 111 \\
\hline & $\mathrm{R}$ - CTGGAGGTATCAAATCCCGCCAAGAA & \\
\hline \multirow[t]{2}{*}{ CYP1A5-like } & F - CCGCTTTCTTCCTACAACTTCATCC & 100 \\
\hline & R - GCCTGCCTTACTGACTTGGTTATTG & \\
\hline \multirow[t]{2}{*}{ CYP2D20-like } & F - CCACAACAAACCCGTCCAAGACAAAC & 135 \\
\hline & $\mathrm{R}$ - CCCATCCGAAGAACCTCCATGATGA & \\
\hline \multirow[t]{2}{*}{ CYP2J6-like } & F - GCCTCATCTAACAGGGACACTAACT & 141 \\
\hline & R - GGAAACAGCAGGTCAACCATTTGATA & \\
\hline \multirow[t]{2}{*}{ CYP2UI-like } & F - CGATCCGTTCCGTAAACTTTGCCATC & 99 \\
\hline & $\mathrm{R}$ - CAACTCTGTCCACACCGATCCTGAAATA & \\
\hline \multirow[t]{2}{*}{ CYP3A11-like } & F - CAAGGAGACAGGTCGCAGTGATTT & 95 \\
\hline & $\mathrm{R}$ - TGTGATCTGAGGAACCGTTGCTTTC & \\
\hline \multirow[t]{2}{*}{ CYP3A25-like } & F - CCAGAGAAGTATGACCCAGAAAGA & 138 \\
\hline & R - AATTGAAATCTTGAGTTCCAGGAGAG & \\
\hline \multirow[t]{2}{*}{ CYP3A29-like } & F - ACACTCTCAAGAAGACAGCCCAGAAC & 120 \\
\hline & $\mathrm{R}$ - GGATACCGAAAGCCGTGGAACTGATTA & \\
\hline \multirow[t]{2}{*}{ FABP-like } & F - GATTGGAGAGGAGTTTGATGAAGT & 86 \\
\hline & R - AGTGAACAAGTGAACCATCTTCTAT & \\
\hline \multirow[t]{2}{*}{ GST_omega-like } & F - CTCTATCTTCTTGTGTGCCAATACC & 120 \\
\hline & R - TCATTCTCTAAGGGTTCGGAGTTT & \\
\hline \multirow[t]{2}{*}{ SULT1B1-like } & F - GGATTGCTGCTGCCATCTAACGAAATC & 132 \\
\hline & $\mathrm{R}$ - AGGAACTGACCATGACTCTGCTTTGT & \\
\hline \multirow[t]{2}{*}{ SULT1C1-like } & F - AGCAGGTACACATTGGGTATCGGAAAT & 124 \\
\hline & R - GATGGCATCAAGACATTCAGGTGTTCG & \\
\hline \multirow[t]{2}{*}{ SULT4A1-like } & F - CGTACTGGCACATTGAACTATCACG & 148 \\
\hline & R - TCCCTTTACCGTTCCTCATCTCTTC & \\
\hline \multirow[t]{2}{*}{ FMO-like } & F - GTGACACTCTGACGAGAGGAATGGAAAG & 85 \\
\hline & R - AAATGACGAAGAAGTGACGGTGGACA & \\
\hline
\end{tabular}

tion time of certified standard and mass to charge ratio $(\mathrm{m} / \mathrm{z})$ of the quantitation ion. The method detection limit for phenanthrene was $3.48 \mathrm{ng} \mathrm{g}^{-1}$ and its recovery ranged from 95 to $105 \%$.

\subsection{Enzyme assays}

Gill samples from all groups $(\mathrm{n}=10)$ were weighed and individually homogenized in 1:4 (w:v) chilled buffer (50 mM Tris-HCl, $\mathrm{pH}$ 7.6, containing $0.5 \mathrm{M}$ sucrose, $1 \mathrm{mM}$ DTT, $1 \mathrm{mM}$ EDTA, $0.15 \mathrm{M} \mathrm{KCl}$, $0.1 \mathrm{mM}$ PMSF) using a Tissue-Tearor ${ }^{\mathrm{TM}}$ homogenizer. Homogenates were centrifuged at $9000 \mathrm{~g}$ for $30 \mathrm{~min}$ at $4{ }^{\circ} \mathrm{C}$, followed by another centrifugation of the supernatant at $100,000 \mathrm{~g}$ for $1 \mathrm{~h}$ at $4{ }^{\circ} \mathrm{C}$ to obtain the cytosolic fraction (supernatant).

Catalase (CAT) activity was measured through the decomposition of $\mathrm{H}_{2} \mathrm{O}_{2}$ by the decrease in absorbance at $240 \mathrm{~nm}$, according to Beutler (1975). Superoxide dismutase (SOD) activity was determined by the inhibition of cytochrome $\mathrm{c}$ reduction in the presence of an $\mathrm{O}_{2}{ }^{\circ}$ - generator system (xanthine/xanthine oxidase) at $550 \mathrm{~nm}$ (McCord and Fridovich, 1969). Glutathione peroxidase (GPx) was measured by the NADPH oxidation rate at $340 \mathrm{~nm}$ using cumene hydroperoxide as substrate according to Wendel (1981). Glutathione reductase (GR) was measured by the NADPH oxidation rate at $340 \mathrm{~nm}$ in the presence of oxidized glutathione (Carlberg and Mannervik, 1985). Glucose 6-phosphate dehydrogenase (G6PDH) activity was determined by the increase in absorbance at $340 \mathrm{~nm}$ caused by reduction of NADP+ to NADPH in the presence of glucose 6-phosphate (Glock and McLean 1953). GST activity was determined according to Keen et al. (1976); the method is based on the conjugation of 1-chloro-2,4-dinitrobenzene (CDNB) to glutathione, monitored at $340 \mathrm{~nm}$. Total protein levels were quantified according to Bradford (1976) using bovine serum albumin as standard.

\subsection{Lipid peroxidation}

The levels of lipid peroxidation in gills were assessed by the quantification of the product formed by the reaction of malondialdehyde (MDA) and thiobarbituric acid (TBA). For this analysis $100 \mathrm{mg}$ of samples were homogenized in $0.3 \mathrm{~mL}$ of Tris buffer $0.1 \mathrm{M}$ ( $\mathrm{pH}$ 8.0). Then, $40 \mathrm{mg}$ of TBA was dissolved in $10 \mathrm{~mL}$ of $0.2 \mathrm{M} \mathrm{HCl}$ and $0.3 \mathrm{~mL}$ of this solution was added to each sample. This mixture was heated at $90^{\circ} \mathrm{C}$ for $40 \mathrm{~min}$. Next, $1 \mathrm{~mL}$ of $n$-butanol was added and samples were centrifuged at $3500 \mathrm{rpm}$ for $3 \mathrm{~min}$. The supernatant was collected and quantified by high performance liquid chromatography coupled at $532 \mathrm{~nm}$, in terms of a malondialdehyde (MDA) standard calibration curve that had been previously prepared using the same sample procedure (Arantes Felício et al., 2015).

\subsection{Gene selection and transcriptional levels}

The following genes of interest were selected from $N$. nodosus transcriptome database (manuscript in preparation): CYP1A1-like, CYP1A5-like, CYP2D20-like, CYP2J6-like, CYP2UI-like, CYP3A11-like, CYP3A25-like, CYP3A29-like, FABP-like, GST_omega-like, SULT1B1like, SULT1C1-like, SULT4A1-like and FMO-like. Primers were designed with OligoAnalyzer ${ }^{\circledR}$ and PrimerQuest ${ }^{\circledR}$ (IDT, http:// www.idtdna.com) software based on the complete and/or partial messenger RNA (mRNA) sequences. The primer sequences are described in Table 1.

Total RNA was extracted from tissues $(100 \mathrm{mg})$ using QIAzol Lysis Reagent (Qiagen) according to the manufacturer's protocol (Qiagen, 2009a). RNA concentration and purity were measured using a NanoDrop ${ }^{\circledR}$ ND-1000 Spectrophotometer (Thermo Scien- 


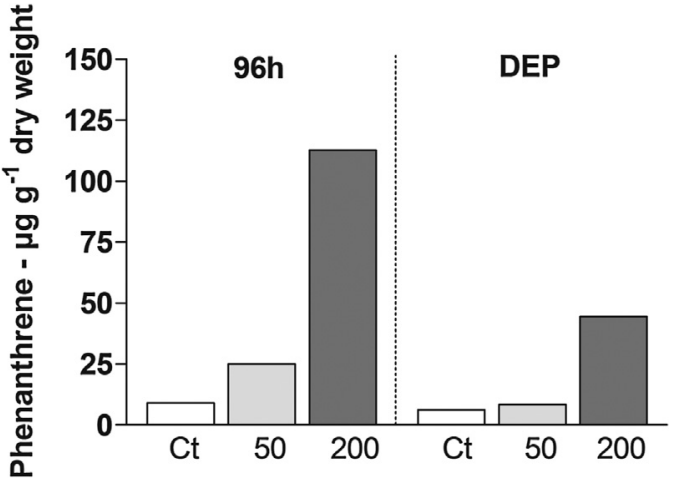

Fig. 1. Phenanthrene levels $\left(\mu \mathrm{gg}^{-1}\right.$ ) on a dry weight basis detected in whole soft tissues of scallops from both control and exposed groups (50 and $200 \mu \mathrm{gL}^{-1}$ ) after $96 \mathrm{~h}$ of exposure and $96 \mathrm{~h}$ depuration ( $\mathrm{n}=10$ animals per group).

tific). The reverse transcription was performed with QuantiTect ${ }^{\circledR}$ Reverse Trancription Kit (Qiagen 2009b), using $1 \mu \mathrm{g}$ of total RNA. The complementary DNA (cDNA) quantification from each sample was measured using NanoDrop ${ }^{\circledR}$ at $260 \mathrm{~nm}$ and diluted with nuclease-free water (Sigma) before use. The aliquots of diluted cDNA were stored at $-20^{\circ} \mathrm{C}$.

Real-time reactions were performed with $100 \mathrm{ng}$ of template cDNA per reaction following QuantiFast ${ }^{\circledR}$ SYBR $^{\circledR}$ Green PCR kit methodology (Qiagen, 2011) using Real-time cycler Rotor Gene Q Qiagen ${ }^{\circledR}$ and Rotor Gene 6000 Series software. Cycling conditions were set as: PCR initial heat activation $\left(95^{\circ} \mathrm{C}\right.$ for $5 \mathrm{~min}$ ), denaturation $\left(95^{\circ} \mathrm{C}\right.$ for $\left.10 \mathrm{~s}\right)$, and combined annealing/extension $\left(60^{\circ} \mathrm{C}\right.$ for $\left.30 \mathrm{~s}\right)$. For all reactions, 40 cycles of denaturation and annealing/extension were performed. Samples were verified by gel electrophoresis to check for single amplicons and primer dimers. Relative mRNA expression ratio for each gene was analyzed using an efficiency corrected $2^{-\Delta \mathrm{Ct}}$ method, normalized by the geometric mean of two endogenous reference gene, Elongation factor-1-like (Ef1-like) and 40 s ribosomal protein-like (40s-like) (Hellemans et al., 2007; Schmittgen and Livak, 2008).

\subsection{Statistical analysis}

For all parameters, normality (Shapiro-Wilks test) and homogeneity of variances assumptions were previously checked (Bartlett's test) and outliers were excluded according to the Grubbs test. When necessary, data were normalized using the logarithmic transformation $(\mathrm{Y}=\log (\mathrm{Y}))(\mathrm{Zar}, 1999)$. Parametric data was analyzed by one-way ANOVA followed by Tukey's post hoc test to evaluate any significant differences $(p<0.05)$ among groups. For non-parametric data, Kruskal-Wallis test was performed, followed by Dunn's test. Results are presented as mean \pm standard deviation (SD).

\section{Results}

\subsection{Tissue PHE concentration}

The levels of PHE detected in tissues of scallops (ng ${ }^{-1}$ dry weight) exposed to nominal concentrations of 50 and $200 \mu \mathrm{g} \mathrm{L}^{-1}$ PHE after $96 \mathrm{~h}$ were 2.7 fold and 12.5 fold higher when compared with control group ( $9.00 \mathrm{ng} \mathrm{g}^{-1}$ dry weight), respectively (Fig. 1). After DEP, PHE levels decreased 2.9 and 2.5 fold in 50 and $200 \mu \mathrm{g} \mathrm{L}^{-1}$ PHE treatments, respectively, in relation to the respective $96 \mathrm{~h}$ groups (Fig. 1). Organisms exposed to $50 \mu \mathrm{g} \mathrm{L}^{-1}$ and submitted to depuration for $96 \mathrm{~h}$ showed PHE values close to control group lev- els, while animals exposed to PHE $200 \mu \mathrm{g} \mathrm{L}^{-1}$ followed by DEP still presented PHE levels 4.9 fold higher than control group (Fig. 1).

\subsection{PHE effects on gene transcription levels in gills}

Three genes involved in phase I biotransformation showed a marked upregulation in the gill of scallops expose to $200 \mu \mathrm{g} \mathrm{L}^{-1}$ PHE after $24 \mathrm{~h}$ and $96 \mathrm{~h}$ when compared to control group (Ct): CYP2D20-like levels of transcription increased 2.95 fold and 5.6 fold (Fig. 2A), respectively, as well as CYP2UI-like levels increased 2.05 and 2.4 fold (Fig. 2B). CYP3A11-like levels only showed an increased following exposure of $200 \mu \mathrm{g} \mathrm{L}^{-1}$ PHE after $96 \mathrm{~h}$ (Fig. 2C), while other analyzed CYP isoforms remained unchanged (Supplementary Fig. S1A-E in the online version at DOI: 10.1016/j.aquatox.2016.05. 025).

For phase II biotransformation genes, GST_omega-like transcript levels increased 1.6 and 2.3 fold after $24 \mathrm{~h}$ and $96 \mathrm{~h}$ of exposure to $200 \mu \mathrm{g} \mathrm{L}^{-1}$ PHE, respectively (Fig. 2D). Similar response was observed in the transcript levels of SULT1B1-like which increased 7.8 and 11.4 fold in the same exposure conditions (Fig. 2E).

This gene was even up-regulated in the group exposed for $96 \mathrm{~h}$ to $50 \mu \mathrm{g} \mathrm{L}^{-1}$ PHE (Fig. 2E). Two other sulfotransferases isoforms, SULT1C1-like (Supplementary Fig. S1H in the online version at DOI: 10.1016/j.aquatox.2016.05.025) and SULT4A1-like (Fig. 2F) remained unchanged after PHE exposure, as well as FMO and FABP (Supplementary Fig. S1 F and G in the online version at DOI: 10. 1016/j.aquatox.2016.05.025, respectively).

DEP caused a reestablishment of transcript levels for all upregulated genes, except for SULT1B1, which remained higher (5.95 fold, Fig. 2E) than control group. In addition, SULT4A1-like levels showed a down-regulation after DEP in the $200 \mu \mathrm{g} \mathrm{L}^{-1}$ PHE exposure (3 fold, Fig. 2F).

\subsection{PAH effects on biochemical responses: enzymes and lipid peroxidation}

Scallops exposed to $200 \mu \mathrm{g} \mathrm{L}^{-1}$ PHE for $96 \mathrm{~h}$ presented higher GPx (1.34 fold, Fig. 3A) and GR (1.7 fold, Fig. 3B) activities. Enhanced G6PDH activity was observed in the organisms exposed to $50 \mu \mathrm{g} \mathrm{L}^{-1}$ PHE for $24 \mathrm{~h}$ and in the organisms depurated for $96 \mathrm{~h}$ (1.24 fold, Fig. 3E). DEP was able to restore GR and GPx activities to control levels (Fig. 3A and B). Interestingly, the clams exposed to $200 \mu \mathrm{g} \mathrm{L}^{-1}$ PHE for $96 \mathrm{~h}$ and depurated for $96 \mathrm{~h}$ showed higher CAT activity (1.66 fold, Fig. 3C) and lower SOD activity (1.2 fold, Fig. 3D). G6PDH activity was also significantly increased (1.2 fold, Fig. 3E) in the group depurated for $96 \mathrm{~h}$ which has been previously exposed to $50 \mu \mathrm{g} \mathrm{L}^{-1}$ PHE. No significant changes among groups were observed in GST activity (Fig. 3F).

Scallops exposed to $200 \mu \mathrm{g} \mathrm{L}^{-1}$ PHE for $24 \mathrm{~h}$ and $96 \mathrm{~h}$, as well as the group depurated for $96 \mathrm{~h}$ showed lower levels of lipid peroxidation than the respective control groups (Fig. 3G).

\section{Discussion}

Considering that bivalves are sessile (e.g. oysters, mussels) or low-movement organisms (e.g. scallops), they show low ability to escape from a point source of contaminants. Because of that, they have been widely used as sentinel organisms, since they tend to bioconcentrate contaminants. Many authors found evidences that bivalves show low PAH metabolism capacity, which reinforce the use of these organisms as important sentinel species for the evaluation of chemical contamination in coastal regions (Livingstone, 1998; Snyder, 2000).

However, the present study shows interesting data evidencing that scallops $N$. nodosus possess molecular and biochemical strate- 

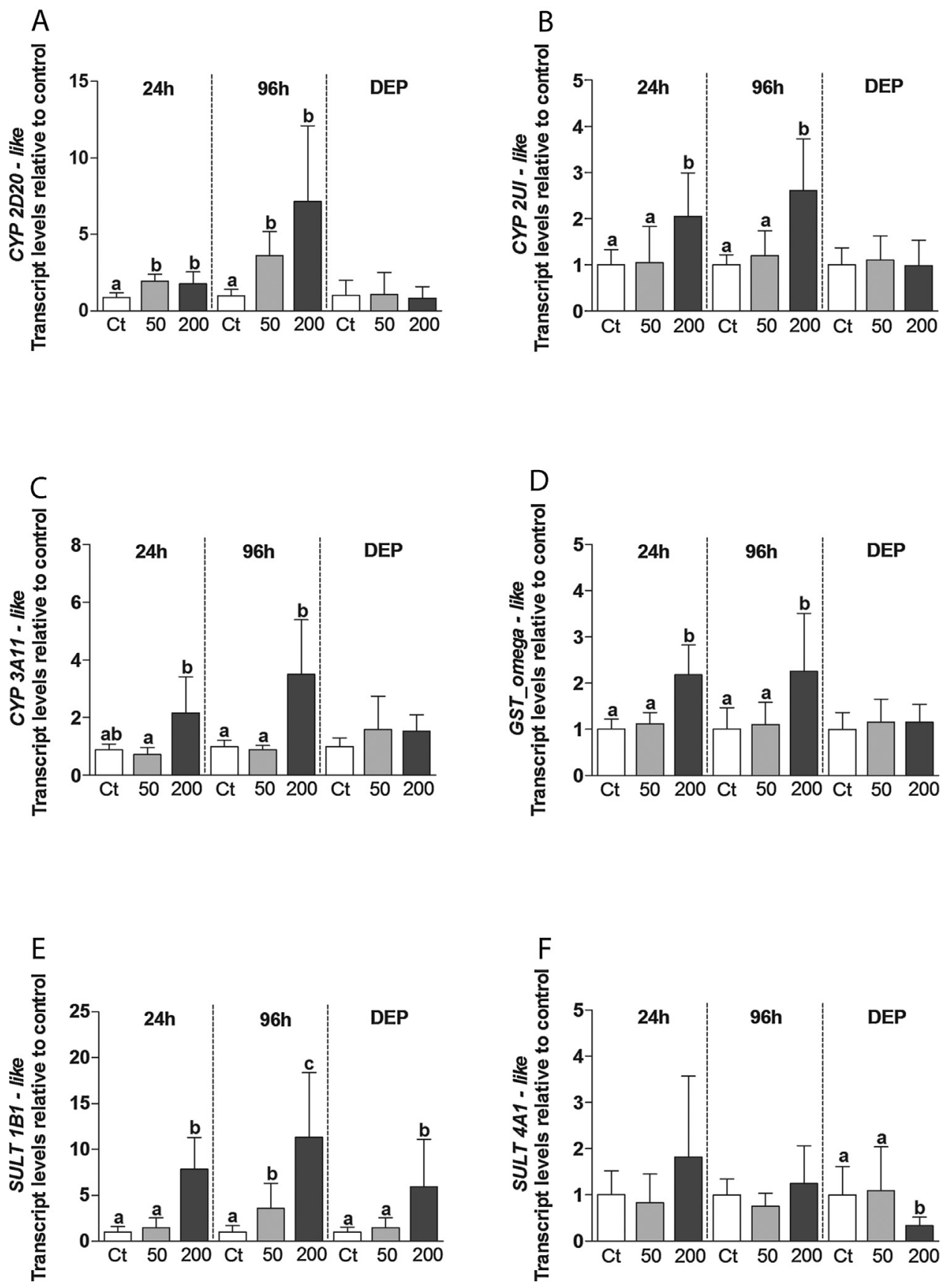

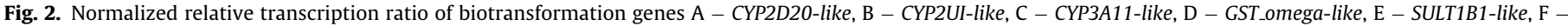

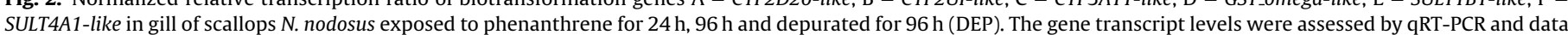

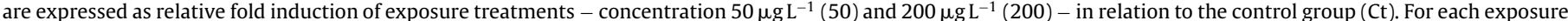
period $(24 \mathrm{~h}, 96 \mathrm{~h}$ or DEP) columns not sharing letters are significant different $(\mathrm{p}<0.05), \mathrm{n}=10$ animals per group.

gies which are possibly involved in the adaptation to PHE exposure, PHE metabolism and depuration.

$N$. nodosus bioconcentrated PHE in a time- and concentrationdependent manner, similarly to what has been observed previously in oysters Crassostrea brasiliana (Lüchmann et al., 2014). Increased PAHs levels have been described in many bivalves, such as scallops Pecten maximus (Hannam et al., 2010a), Perna viridis (Cheung et al., 2001), Ruditapes philippinarum (De Luca-Abbott et al., 2005; Liu et al., 2014), Mytilus galloprovincialis (Bocchetti et al., 2008) and Chlamys islandica (Hannam et al., 2009).

An important route for uptake, bioconcentration, metabolism and excretion of PAHs are the gills because of their wide surface area in contact with seawater. In this context, it is expected that this tissue possesses molecular and biochemical modulation systems more rapidly responsive than digestive gland. This has been demonstrated by Pan et al. (2009) in scallops exposed to benzo[a]pyrene and by Trevisan et al. (2012) in oysters exposed to CDNB. Therefore, this tissue can be target by several pollutants in aquatic organisms, probably affecting different metabolic and cellular pathways.

In the present study, the transcription of eight different CYP genes were analyzed in gills of scallops exposed to PHE. Three of them, CYP2D20-like, CYP2UI-like and CYP3A11-like, showed significantly higher transcript levels in the organisms exposed both, for 24 and $96 \mathrm{~h}$ period, to $200 \mu \mathrm{g} \mathrm{L}{ }^{-1} \mathrm{PHE}$, comparing to the control group. Similar effect was observed in the transcription of CYP2D10-like 


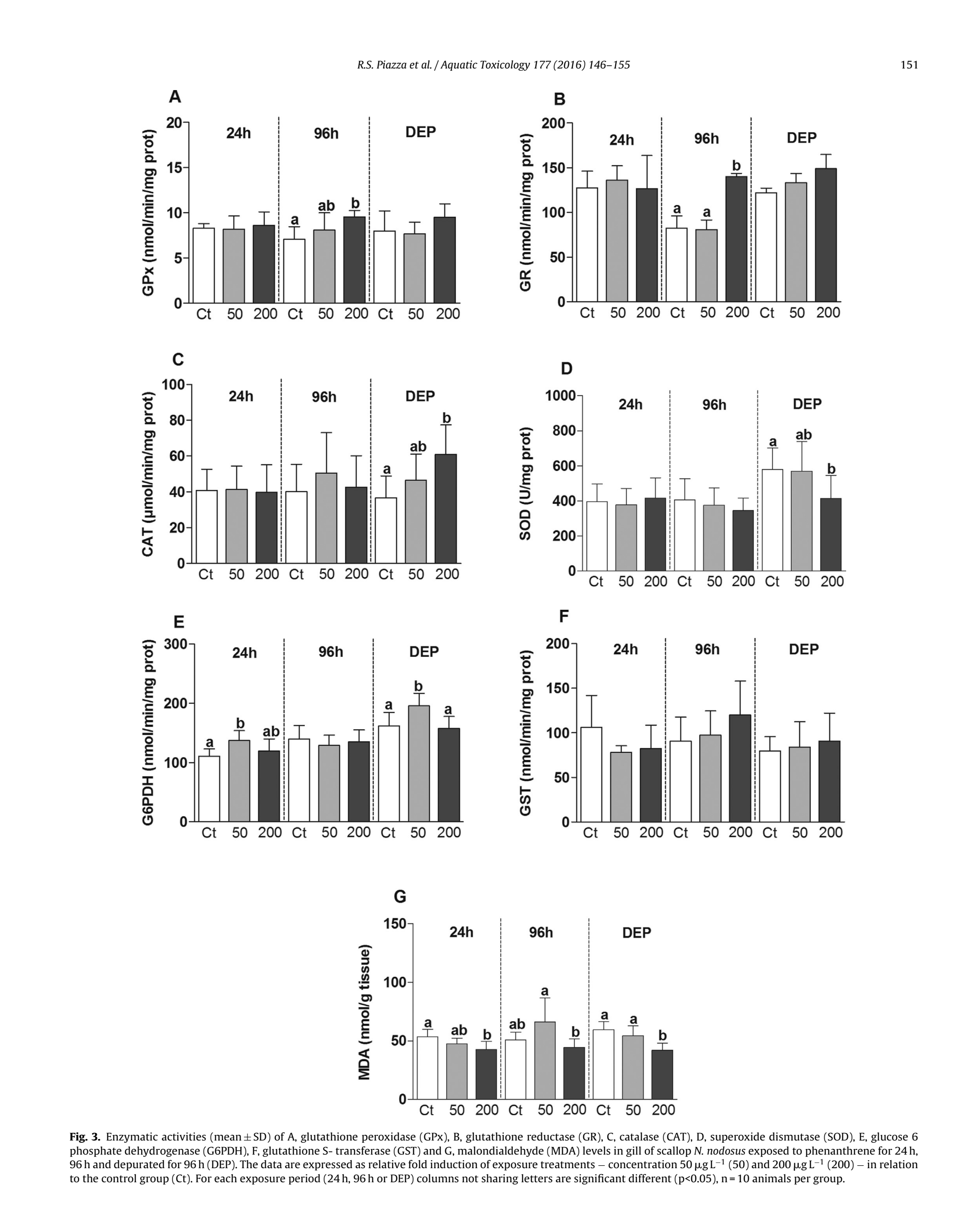


even in the group exposed to the lower PHE concentration. These data indicate that PHE is activating the transcription of different phase I enzymes possibly to enhance its metabolism and depuration. Corroborating this hypothesis, increased transcript levels of GST omega-like and SULT 1B1-like were also up-regulated in the scallops exposed for 24 and $96 \mathrm{~h}$ to $200 \mu \mathrm{g} \mathrm{L}^{-1}$ PHE (Fig. 2D and E).

The biotransformation of such compounds can also produces ROS, which are also generated through aerobic metabolism, electron transport chain, enzymatic activities or immunological reaction (Regoli and Giuliani, 2013).

Interestingly, MDA levels decreased after exposure $(24 \mathrm{~h})$ to the highest PHE concentration, remaining low even after DEP. This pattern has already been reported with other aquatic species exposed to PAH mixtures (Arantes Felício et al., 2015; Nogueira et al., 2015) and on a time-dependent oxidative damage (Ansaldo et al., 2005; Lüchmann et al., 2011, 2014). At the same time, the absence of increased MDA levels along with PHE bioaccumulation could indicate a low acute toxicity of this compound to N. nodosus. On the other hand, it is known that different aldehyde dehydrogenases are capable of reducing MDA and some other aldehyde products of lipid peroxidation to the corresponding alcohols, suggesting a potential physiological role for these enzymes in detoxifying cytotoxic aldehydes (Janero, 1990). Previous studies showed that a possible biochemical pathway for MDA degradation and excretion involves its oxidation by mitochondrial aldehyde dehydrogenase followed by decarboxylation to produce acetaldehyde, which is oxidized by aldehyde dehydrogenase to acetate and further to $\mathrm{CO}_{2}$ and $\mathrm{H}_{2} \mathrm{O}$ (Siu and Draper, 1982; Esterbauer et al., 1991). Based on that, we could suggest that exposure to PHE could induce aldehyde dehydrogenase which, in turns, could decompose MDA to more soluble alcohols to be excreted in the gills. This hypothesis is corroborated by the fact that aldehyde dehydrogenase genes have been identified in the list of up-regulated genes in oysters Crassostrea brasiliana exposed to PHE (K.H.Luchmann, personal communication). Likewise, aldehyde dehydrogenase mitochondrial type-coding genes have been identified in the group of the up-regulated genes in scallops Nodipecten nodosus exposed in situ to produced water discharges at petroleum exploration platforms (Wendt et al., manuscript in preparation).

PHE caused an increase in activity of three antioxidant enzymes related to the glutathione system, namely GR, GPx and G6PDH. These points to a scenario with increased reduced glutathione turnover, peroxide detoxification and NADPH consumption, probably related to an increased ROS production during PHE metabolism. It is known that the GPx system is essential for protection against peroxide in bivalves, and impairment on its ancillary systems (such as the GR cycle) can decrease the in vivo organic peroxide detoxification and increase animal susceptibility to oxidative stress in mussels (Trevisan et al., 2014a,b). GST, another enzyme that confers cellular protection during PHE exposure, did not show changes in activity after PHE exposure, agreeing with previously studies done with Nacella concinna, Mytilus galloprovincialis and Crassostrea brasiliana (Ansaldo et al., 2005; Lüchmann et al., 2011; Trisciani et al., 2012). GST activity has been reported to increase and decrease in marine bivalves expose to pollutants. These opposed results could be explained by inhibitory effect caused by high concentration of pollutants, or alternatively, an adaptive response of GST detoxification pathway that would need to be further studied (Pan et al., 2009). Moreover, GST activity was analyzed using CDNB as substrate, which quantifies total GST activity, and this protocol does not allow the identification of activation of inactivation of GST isoforms specifically (Trisciani et al., 2012). Therefore, the lack of enzymatic response of GST after PHE exposure does not mean that specific GST isoforms were not responsive to PHE. This could be further addressed by the use of additional and more specific GST substrates. In fact, increased GST-omega-like mRNA levels ( $\sim 2$ fold) were observed in organisms exposed for $24 \mathrm{~h}$ and $96 \mathrm{~h}$ to the higher PHE concentration.

Interestingly, enzymatic activity was mainly modulated after $96 \mathrm{~h}$ of PHE exposure, suggesting that $24 \mathrm{~h}$ might not have been long enough to activate the antioxidant defense system, except for G6PDH activity. Although responsible for the NADPH generation, this enzyme is related to glucose metabolism, and probably, to feeding/starvation periods. Feeding was not supplied during PHE exposure, returning during the depuration period. Although this scenario may affect energy-related metabolism, it should not be considered as a general rule since no-effect and reduction of G6PDH activity was reported during food deprivation in oyster gill and fish liver (Lüchmann et al., 2011; Morales et al., 2004).

In this study, it was analyzed mRNA expression of PAH detoxification genes in gill of scallops. Despite CYP1A plays an important role in this mechanism and was the most important and studied gene related by chemical detoxification via the aryl hydrocarbon receptor (AHR) (Toledo-Silva et al., 2008; Goldstone and Stegeman, 2006; Zanette et al., 2013), the present transcriptional results showed non-significant changes in the CYP1A1-like and CYP1A5like genes. The interpretation of results related to CYP1As has been hindered by the low catalytic activity of microsomal enzymes and the lack of specific cross-reactivity of antibodies for these proteins in bivalves (Zanette et al., 2013). Our results are in agreement with Akcha et al. (2000) that showed no differences on the level of CYP1A-like immunopositive proteins in digestive gland of Mytilus galloprovincialis exposed to benzo[a]pyrene. Zanette et al. (2013) also verified no significant changes in the levels of mRNA expression of the CYP1-like and CYP3- like genes in digestive gland and gill of Mytilus edulis after injections of AHR agonists.

Other and equally important subfamily is known such CYP2 and performs an important function in the biotransformation of organic compounds (Kim et al., 2014). CYP2 also has been previously reported in mammals, fish and mollusks (Goldstone et al., 2010; Kubota et al., 2013; Lüchmann et al., 2014; Peters et al., 1998). Agreeing with CYP2 role in detoxification of PAHs, mRNA levels of CYP2D20-like and CYP2UI-like increased significantly in the gill of scallops both, after $24 \mathrm{~h}$ and $96 \mathrm{~h}$ exposure to PHE. Important to note that after depuration treatment the transcriptional levels both CYP2 s were nearly identical to the control, not presenting significant differences. These results further confirm that CYP2 transcriptional changes could be suggested as biomarkers of exposure to PAH in bivalves. The CYP3 subfamily is known to metabolize a several range of substrates such as xenobiotics, bile acids, endogenous sex hormones and prevent bioaccumulation of lipophilic substances (Tian et al., 2014). Notably, we found an increase in the CYP3A11-like after $96 \mathrm{~h}$ of exposure to higher PHE treatment returning to basal levels after DEP. Compared to previous studies we can observe a discrepancy in results such as moderate upregulation or absence of change in CYP3 isoforms for fishes and bivalves exposed to organic contaminants (Della Torre et al., 2010; Han et al., 2014; Lüchmann et al., 2014; Zanette et al., 2013). A possible explanation for these different outcomes could be due to tissue distribution, exposure time and concentration. While recent studies have shown increases as well as decreases or blocked induction in CYP expression (Toledo-Silva et al., 2008; Lacroix et al., 2014; Tian et al., 2014), such divergences still lack a mechanistic explanation that would support inference and prediction (Zanette et al., 2013). Another phase I gene analyzed in this study was FMO-like. This gene did not present any significant variation to PHE exposure, as already verified by Boutet et al. (2004a) in gills of oyster Crassostrea gigas following pesticide and hydrocarbon exposure. Schlenk and Buhler, (1989) detected FMO enzyme activity in C. gigas gill, while Boutet et al. (2004a) showed a rise of FMO transcripts levels in digestive gland of $C$. gigas exposed to PAHs and suggested that FMO levels 
was normally greater in digestive gland, liver or hepatopancreas than in others tissues.

After phase I, metabolites can be conjugated to endogenous compounds by phase II biotransformation enzymes such as GST isoforms which is known to promote differential regulation (Lacroix et al., 2014). As stated before, an increment in mRNA levels of GSTomega-like ( $\sim 2$ fold) was observed in organisms exposed for $24 \mathrm{~h}$ and $96 \mathrm{~h}$ to higher levels of PHE. GST-omega class also has been identified of up-regulated genes in oysters exposed to hydrocarbon (Boutet et al., 2004b; Lüchmann et al., 2014), domestic sewage (Medeiros et al., 2008a) and in transplanted zebra mussels (Châtel et al., 2015). This GST isoform is also suggested to be involved in the antioxidant defense system (Medeiros et al., 2008a; Rola et al., 2012), that can be important during PAH exposures.

Cytosolic SULT belong to a superfamily of multifunctional phase II enzymes that catalyze sulfate conjugation in the metabolism of xenobiotics and endogenous compounds (Michio and Hiroshi, 1994). There are few studies with these proteins in bivalves. (Wang et al., 2012) suggested SULT might be a candidate gene related to growth in clams and Jia et al. (2009) related it to stress responses in abalone. SULT1C1-like levels did not present significantly changes in our study, as in oyster Crassostrea brasiliana from a polluted site at southern Brazil (unpublished data). However, SULT1B1-like presented a major increase by PHE exposure, a result previously observed in bivalves exposed to benzo[a]pyrene (Liu et al., 2014; Milan et al., 2013; Tian et al., 2013). This gene remained elevated even after the depuration period in the organisms exposed to the higher PHE concentration, which suggests a possible key role on PHE detoxification in gills.

Another gene investigated in our study was FABP, a small (14-15 kDa) cytosolic protein which belongs to the large multigene family of intracellular lipid-binding proteins. Vertebrate FABPs are involved in energy pathways, growth and development, fatty acid transport between membranes but other biological roles are being investigated, such as participation on signal transduction, regulation of gene expression and involvement in mediating the absorption and metabolism of xenobiotics (Medeiros et al., 2008b). The FABP mRNA levels did not show significant differences in our study, nonetheless, showed an increase in FABP levels in gill oyster $C$. brasiliana (unpublished data) and $C$. gigas (Medeiros et al., 2008b), contaminated by sewage. Conversely Bain (2002) reported an inhibition of FABP levels after pyrene exposure in fish heart. It is still unclear the role of FABP in bivalves exposed to xenobiotics.

Like other bivalves, scallops are able to eliminate PAHs from its tissues when in contact to clean seawater under conditions able to maximize their filtering activity. The present study used a flowthrough water systems depuration to evaluate the detoxification capacity of scallops. Depuration caused a decrease in PHE concentration by 2.9 - and 2.5 fold after $96 \mathrm{~h}$ of exposure to PHE 50 and $200 \mu \mathrm{g} \mathrm{L}^{-1}$, respectively, as well as the restoration to basal levels for most of the parameters affected by PHE exposure. Decrease of PHE levels can lead to animal recovery, with a probable lower signaling input for gene transcription and lower ROS production due to decreased PHE biotransformation. Even though, at the end of DEP scallops still presented modulation of key cellular defense mechanisms, such as lower SULT4A1 transcript levels and SOD activity, as well as increased CAT and G6PDH activities. Some of the sulfate conjugates are known to become toxic or pharmacologically active (Michio and Hiroshi, 1994), which may lead to reduction of SULT mRNA levels (Chapman et al., 2004) and enzymatic activity (Janer et al., 2005). Decreased SOD activity in parallel to increased CAT activity suggests an effort to stabilize $\mathrm{H}_{2} \mathrm{O}_{2}$ concentration, minimizing oxidative stress and lipid peroxidation (Ameur et al., 2015). In addition, at low $\mathrm{H}_{2} \mathrm{O}_{2}$ concentrations, CAT modulates the detoxification of other substrates, such as phenols and alcohols, over reactions coupled to $\mathrm{H}_{2} \mathrm{O}_{2}$ reduction (Regoli and Giuliani, 2013).
In conclusion, data suggests that scallops can adopt some strategies to metabolize, eliminate and survive in the presence of PHE. The transcription genes associated to cellular parameters develop an important role in the characterization of the detoxification mechanisms in bivalves. PHE was responsible by alterations in membrane stability and important genes related to PHE biotransformation. Induction of phase I and II biotransformation genes during the exposure period is possibly associated to decreased levels of PHE in the tissues of scallops submitted to $96 \mathrm{~h}$ depuration. Depuration in clean water associated to feeding could be an effective method to be used in order to minimize the effects induced by PAHs and promoting their excretion, possibly by the gill in scallop N. nodosus.

\section{Acknowledgments}

This work was supported by CNPq (National Council for Research Development). We would like to thank M.Sc. Clei E. Piazza, Isis M. R. Martins and Marisa Bercht for the assistance during experiments. We are grateful to Dr. Cláudio M.R. Melo for allowing the use of LMM infrastructure. ACDB, EAA and MCB are recipients of CNPq productivity fellowships.

\section{References}

Akcha, F., Izuel, C., Venier, P., Budzinski, H., Burgeot, T., Narbonne, J.-F., 2000. Enzymatic biomarker measurement and study of DNA adduct formation in benzo[a]pyrene-contaminated mussels. Mytilus Galloprovincialis Aquat. Toxicol. 49, 269-287, http://dx.doi.org/10.1016/S0166-445X(99)00082-X.

Ameur, W., Ben, El, Megdiche, Y., de Lapuente, J., Barhoumi, B., Trabelsi, S., Ennaceur, S., Camps, L., Serret, J., Ramos-López, D., Gonzalez-Linares, J., Touil, S., Driss, M.R., Borràs, M., 2015. Oxidative stress, genotoxicity and histopathology biomarker responses in Mugil cephalus and Dicentrarchus labrax gill exposed to persistent pollutants. A field study in the Bizerte Lagoon: Tunisia. Chemosphere 135, 67-74, http://dx.doi.org/10.1016/j.chemosphere. 2015.02.050.

Ansaldo, M., Najle, R., Luquet, C.M., 2005. Oxidative stress generated by diesel seawater contamination in the digestive gland of the Antarctic limpet Nacella concinna. Mar. Environ. Res. 59, 381-390, http://dx.doi.org/10.1016/j. marenvres.2004.06.003.

Arantes Felício, A., Martins Parente, T.E., Regina Maschio, L., Nogueira, L., Rodrigues Venancio, L.P., de Freitas Rebelo, M., Schlenk, D., de Almeida, E.A., 2015. Biochemical responses, morphometric changes, genotoxic effects and CYP1A expression in the armored catfish Pterygoplichthys anisitsi after 15 days of exposure to mineral diesel and biodiesel. Ecotoxicol. Environ. Saf. 115, 26-32, http://dx.doi.org/10.1016/j.ecoenv.2015.01.034.

Bain, L.J., 2002. cDNA cloning, sequencing, and differential expression of a heart-type fatty acid-binding protein in the mummichog (Fundulus heteroclitus). Mar. Environ. Res. 54, 379-383, http://dx.doi.org/10.1016/S01411136(02)00130-7.

Bayır, M., Bayır, A., Wright, J.M., 2015. Divergent spatial regulation of duplicated fatty acid-binding protein (fabp) genes in rainbow trout (Oncorhynchus mykiss). Comp. Biochem. Physiol. Part D. Genomics Proteomics 14, 26-32, http://dx.doi.org/10.1016/j.cbd.2015.02.002.

Beutler, E., 1975. Red Cell Metabolism: A Manual of Biochemical Methods. Grune \&Stratton, New York.

Bocchetti, R., Fattorini, D., Pisanelli, B., Macchia, S., Oliviero, L., Pilato, F., Pellegrini, D., Regoli, F., 2008. Contaminant accumulation and biomarker responses in caged mussels Mytilus galloprovincialis, to evaluate bioavailability and toxicological effects of remobilized chemicals during dredging and disposal operations in harbour areas. Aquat. Toxicol. 89, 257-266, http://dx.doi.org/10. 1016/j.aquatox.2008.07.011.

Boutet, I., Tanguy, A., Moraga, D., 2004a. Molecular identification and expression of two non-P450 enzymes, monoamine oxidase A and flavin-containing monooxygenase 2 , involved in phase I of xenobiotic biotransformation in the Pacific oyster, Crassostrea gigas. Biochim. Biophys. Acta 1679, 29-36, http://dx. doi.org/10.1016/j.bbaexp.2004.04.001.

Boutet, I., Tanguy, A., Moraga, D., 2004b. Response of the Pacific oyster Crassostrea gigas to hydrocarbon contamination under experimental conditions. Gene 329, 147-157, http://dx.doi.org/10.1016/j.gene.2003.12.027.

Bradford, M., 1976. A rapid and sensitive method for the quantification of microgramquantities of protein utilizing the principle of protein-dye binding. Anal. Biochem. 72, 248-254, http://dx.doi.org/10.1016/0003-2697(76)905273.

Carlberg, I., Mannervik, B., 1985. Glutathione reductase. Meth. Enzymol. 113 484-490, http://dx.doi.org/10.1016/S0076-6879(85)13062-4.

Châtel, A., Faucet-Marquis, V., Gourlay-Francé, C., Pfohl-Leszkowicz, A., Vincent-Hubert, F., 2015. Genotoxicity and activation of cellular defenses in 
transplanted zebra mussels Dreissena polymorpha along the Seine river. Ecotoxicol. Environ. Saf. 114, 241-249, http://dx.doi.org/10.1016/j.ecoenv. 2014.03.023.

Chapman, E., Best, M.D., Hanson, S.R. and Wong, C.-H., 2004. Sulfotransferases: Structure, Mechanism, Biological Activity, Inhibition, and Synthetic Utility. Angewandte Chemie International Edition, 43: 3526-3548. 10.1002/anie.200300631.

Cheung, C.C., Zheng, G., Li, A.M., Richardson, B., Lam, P.K., 2001. Relationships between tissue concentrations of polycyclic aromatic hydrocarbons and antioxidative responses of marine mussels. Perna Viridis. Aquat. Toxicol. 52, 189-203, http://dx.doi.org/10.1016/S0166-445X(00)00145-4.

Cranford, P.J., 2006. Scallops: biology, ecology and aquaculture, developments in aquaculture and fisheries science, developments. In: Aquaculture and Fisheries Science. Elsevier, http://dx.doi.org/10.1016/S0167-9309(06)80040-2.

De Luca-Abbott, S.B., Richardson, B.J., McClellan, K.E., Zheng, G.J., Martin, M., Lam, P.K.S., 2005. Field validation of antioxidant enzyme biomarkers in mussels (Perna viridis) and clams (Ruditapes philippinarum) transplanted in Hong Kong coastal waters. Mar. Pollut. Bull. 51, 694-707, http://dx.doi.org/10.1016/j. marpolbul.2005.01.010.

Della Torre, C., Corsi, I., Nardi, F., Perra, G., Tomasino, M.P., Focardi, S., 2010. Transcriptional and post-transcriptional response of drug-metabolizing enzymes to PAHs contamination in red mullet (Mullus barbatus Linnaeus, 1758): a field study. Mar. Environ. Res. 70, 95-101, http://dx.doi.org/10.1016/j. marenvres.2010.03.009.

Einsporn, S., Koehler, A., 2008. Immuno-localisations (GSSP) of subcellular accumulation sites of phenanthrene, aroclor 1254 and lead $(\mathrm{Pb})$ in relation to cytopathologies in the gills and digestive gland of the mussel Mytilus edulis. Mar. Environ. Res. 66, 185-186, http://dx.doi.org/10.1016/j.marenvres.2008. 02.053.

Esterbauer, H., Schaur, R.J., Zollner, H., 1991. Chemistry and biochemistry of 4-hydroxynonenal, malonaldehyde and related aldehydes. Free Rad. Biol. Med. 11, 81-128, http://dx.doi.org/10.1016/0891-5849(91)90192-6.

FAO, 2008. Lee, R., Lovatelli, A., Ababouch, L. Bivalve depuration: fundamental and practical aspects. Fisheries Technical Paper n. 511.

Freites, L., García, N., Troccoli, L., Maeda-Martínez, A.N., Fernández-Reiriz, M.J., 2010. Influence of environmental variables and reproduction on the gonadal fatty acid profile of tropical scallop Nodipecten nodosus. Comp. Biochem. Physiol. B. Biochem. Mol. Biol. 157, 408-414, http://dx.doi.org/10.1016/j.cbpb. 2010.09.001.

Glock, G.E., McLean, P., 1953. Further studies on the properties and assay of glucose 6-phosphate dehydrogenase and 6-phosphogluconate dehydrogenase of rat liver. Biochem. J. 55, 400-408.

Goldstone, H.H., Stegeman, J., 2006. A revised evolutionary history of the CYP1A subfamily: gene duplication gene conversion, and positive selection. J. Mol. Evol. 62, 708-717, http://dx.doi.org/10.1007/s00239-005-0134-z.

Goldstone, J., McArthur, A., Kubota, A., Zanette, J., Parente, T., Jonsson, M., Nelson, D., Stegeman, J., 2010. Identification and developmental expression of the full complement of Cytochrome P450 genes in Zebrafish. BMC Genomics 11, 643.

Grintzalis, K., Georgiou, C.D., Dailianis, S., 2012. Total thiol redox status as a potent biomarker of PAH-mediated effects on mussels. Mar. Environ. Res. 81, 26-34, http://dx.doi.org/10.1016/j.marenvres.2012.08.004.

Halliwell, B., Gutteridge, J.M.C., 1985. Free radicals in biology and medicine. J. Free Radic. Biol. Med. 1, 331-332 http://dx.doi.org/10.1016/0748-5514(85)90140-0.

Han, J., Won, E.-J., Hwang, D.-S., Shin, K.-H., Lee, Y.S., Leung, K.M.-Y., Lee, S.-J., Lee, J.-S., 2014. Crude oil exposure results in oxidative stress-mediated dysfunctional development and reproduction in the copepod Tigriopus japonicus and modulates expression of cytochrome P450 (CYP) genes. Aquat. Toxicol. 152, 308-317, http://dx.doi.org/10.1016/j.aquatox.2014.04.027.

Hannam, M.L., Bamber, S.D., Moody, J.A., Galloway, T.S., Jones, M.B., 2009. Immune function in the Arctic Scallop Chlamys islandica, following dispersed oil exposure. Aquat. Toxicol. 92, 187-194, http://dx.doi.org/10.1016/j.aquatox. 2009.01.010.

Hannam, M.L., Bamber, S.D., Galloway, T.S., John Moody, A., Jones, M.B., 2010a Effects of the model PAH phenanthrene on immune function and oxidative stress in the haemolymph of the temperate scallop Pecten maximus. Chemosphere 78, 779-784, http://dx.doi.org/10.1016/j.chemosphere.2009.12. 049.

Hannam, M.L., Bamber, S.D., Galloway, T.S., John Moody, A., Jones, M.B., 2010b. Functional immune response in Pecten maximus: combined effects of a pathogen-associated molecular pattern and PAH exposure. Fish Shellfish Immunol. 28, 249-252, http://dx.doi.org/10.1016/j.fsi.2009.10.018.

Hellemans, J., Mortier, G., De Paepe, A., Speleman, F., Vandesompele, J., 2007. qBase relative quantification framework and software for management and automated analysis of real-time quantitative PCR data. Genome Biol. 8, http:// dx.doi.org/10.1186/gb-2007-8-2-r19, R19-R19.

Janer, G., Mesia-Vela, S., Kauffman, F.C., Porte, C., 2005. Sulfatase activity in the oyster Crassostrea virginica: its potential interference with sulfotransferase determination. Aquat. Toxicol. 74, 92-95, http://dx.doi.org/10.1016/j.aquatox. 2005.05.004

Janero, D.R., 1990. Malondialdehyde and thiobarbituric acid-reactivity as diagnostic indices of lipid peroxidation and peroxidative tissue injury. Free Rad. Biol.Med. 9, 515-540, http://dx.doi.org/10.1016/0891-5849(90)90131-2.

Jia, X., Zhang, Z., Wang, G., Zou, Z., Wang, S., Huang, B., Wang, Y., 2009. Expressed sequence tag analysis for identification and characterization of genes related to Tributyltin (TBT) exposure in the abalone Haliotis diversicolor supertexta.
Comp. Biochem. Physiol. Part D. Genomics Proteomics 4, 255-262, http://dx. doi.org/10.1016/j.cbd.2009.06.002.

Jin, Q., Pan, L., Liu, T., Hu, F., 2015. RNA-seq based on transcriptome reveals differ genetic expressing in Chlamys farreri exposed to carcinogen PAHs. Environ. Toxicol. Pharmacol. 39, 313-320, http://dx.doi.org/10.1016/j.etap.2014.11.019.

Keen, J.H., Habig, W.H., Jakoby, W.B., 1976. Mechanism for the several activities of the glutathione S-transferase. J. Biol. Chem. 251, 6183-6188.

Kim, B.-M., Rhee, J.-S., Jeong, C.-B., Lee, S.-J., Lee, Y.S., Choi, I.-Y., Lee, J.-S., 2014. Effects of benzo[a]pyrene on whole cytochrome P450-involved molecular responses in the marine medaka Oryzias melastigma. Aquat. Toxicol. 152, 232-243, http://dx.doi.org/10.1016/j.aquatox.2014.04.008.

Kubota, A., Bainy, A.C.D., Woodin, B.R., Goldstone, J.V., Stegeman, J.J., 2013. The cytochrome P450 2AA gene cluster in zebrafish (Danio rerio): expression of CYP2AA1 and CYP2AA2 and response to phenobarbital-type inducers. Toxicol. Appl. Pharmacol. 272, 172-179, http://dx.doi.org/10.1016/j.taap.2013.05.017.

Lüchmann, K.H., Mattos, J.J., Siebert, M.N., Granucci, N., Dorrington, T.S., Bícego, M.C., Taniguchi, S., Sasaki, S.T., Daura-Jorge, F.G., Bainy, A.C.D., 2011. Biochemical biomarkers and hydrocarbons concentrations in the mangrove oyster Crassostrea brasiliana following exposure to diesel fuel water-accommodated fraction. Aquat. Toxicol. 105, 652-660 http://dx.doi.org/ 10.1016/j.aquatox.2011.09.003.

Lüchmann, K.H., Dafre, A.L., Trevisan, R., Craft, J.A., Meng, X., Mattos, J.J., Zacchi, F.L., Dorrington, T.S., Schroeder, D.C., Bainy, A.C.D., 2014. A light in the darkness: new biotransformation genes, antioxidant parameters and tissue-specific responses in oysters exposed to phenanthrene. Aquat. Toxicol. 152, 324-334, http://dx.doi.org/10.1016/j.aquatox.2014.04.021.

Lacroix, C., Coquillé, V., Guyomarch, J., Auffret, M., Moraga, D., 2014. A selection of reference genes and early-warning mRNA biomarkers for environmental monitoring using Mytilus spp. as sentinel species. Mar. Pollut. Bull. 86, 304-313, http://dx.doi.org/10.1016/j.marpolbul.2014.06.049.

Liu, D., Pan, L., Li, Z., Cai, Y., Miao, J., 2014. Metabolites analysis, metabolic enzyme activities and bioaccumulation in the clam Ruditapes philippinarum exposed to benzo[a]pyrene. Ecotoxicol. Environ. Saf. 107, 251-259, http://dx.doi.org/10. 1016/j.ecoenv.2014.06.024.

Livingstone, D., 1998. The fate of organic xenobiotics in aquatic ecosystems: quantitative and qualitative differences in biotransformation by invertebrates and fish. Comp. Biochem. Physiol. Part A Mol. Integr. Physiol. 120, 43-49, http://dx.doi.org/10.1016/S1095-6433(98)10008-9.

Martins, M., Costa, P.M., Ferreira, A.M., Costa, M.H., 2013. Comparative DNA damage and oxidative effects of carcinogenic and non-carcinogenic sediment-bound PAHs in the gills of a bivalve. Aquat. Toxicol, 85-95, http://dx doi.org/10.1016/j.aquatox.2013.07.019, 142-143.

McCord, J.M., Fridovich, I., 1969. Superoxide dismutase: an enzymatic function for erythrocuprein (Hemocuprein). J. Biol. Chem. 244, 6049-6055.

McLeod, W.D., Brown, D.W., Friedman, A.J., Burrows, D.G., Maynes, O., Pearce, R.W. Wigren, C.A., Bogar, R.G., 1985. Standard Analytical Procedures of the NOAA National Analytical Facility, 1985-1986. Extractable Toxic Organic Components, 2nd edn. NOAA Northwest Fisheries Science Center, Seattle, WA (U.S. Department of Commerce, NOAA Technical Memo, NMFS-F/NWC-9), p.121.

Medeiros, I.D., Siebert, M.N., de Toledo e Silva, G., Moraes, M.O., Marques, M.R.F., Bainy, A.C.D., 2008a. Differential gene expression in oyster exposed to sewage. Mar. Environ. Res. 66, 156-157, http://dx.doi.org/10.1016/j.marenvres.2008. 02.048

Medeiros, I.D., Siebert, M.N., Toledo-Silva, G., Rodrigues, T.B., Marques, M.R.F., Bainy, A.C.D., 2008b. Induced gene expression in oyster Crassostrea gigas exposed to sewage. Environ. Toxicol. Pharmacol. 26, 362-365, http://dx.doi. org/10.1016/j.etap.2008.05.004.

Michio, M., Hiroshi, H., 1994. Biochemistry and molecular biology of drug-metabolizing sulfotransferase. Int. J. Biochem. 26, 1237-1247, http://dx. doi.org/10.1016/0020-711X(94)90093-0.

Milan, M., Pauletto, M., Patarnello, T., Bargelloni, L., Marin, M.G., Matozzo, V., 2013. Gene transcription and biomarker responses in the clam Ruditapes philippinarum after exposure to ibuprofen. Aquat. Toxicol. 126, 17-29, http:// dx.doi.org/10.1016/j.aquatox.2012.10.007.

Morales, A.E., Pérez-Jiménez, A., Carmen Hidalgo, M., Abellán, E., Cardenete, G., 2004. Oxidative stress and antioxidant defenses after prolonged starvation in Dentex dentex liver. Comp. Biochem. Physiol. Part C Toxicol. Pharmacol. 139 153-161, http://dx.doi.org/10.1016/j.cca.2004.10.008.

Nogueira, L., Garcia, D., Trevisan, R., Sanches, A.L.M., da Silva Acosta, D., Dafre, A.L., Oliveira, T.Y.K., de Almeida, E.A., 2015. Biochemical responses in mussels Perna perna exposed to diesel B5. Chemosphere 134, 210-216, http://dx.doi.org/10. 1016/j.chemosphere.2015.04.034.

Noh, S.R., Cheong, H.-K., Ha, M., Eom, S.-Y., Kim, H., Choi, Y.-H., Paek, D., 2015. Oxidative stress biomarkers in long-term participants in clean-up work after the Hebei Spirit oil spill. Sci. Total Environ., 207-214, http://dx.doi.org/10. 1016/j.scitotenv.2015.02.039, 515-516.

Pan, L., Ren, J., Zheng, D., 2009. Effects of benzo(a)pyrene exposure on the antioxidant enzyme activity of scallop Chlamys farreri. Chin. J. Oceanol. Limnol. 27, 43-53, http://dx.doi.org/10.1007/s00343-009-0043-x.

Peters, L.D., Nasci, C., Livingstone, D.R., 1998. Variation in levels of cytochrome P4501A 2B, 2E, 3A and 4A-immunopositive proteins in digestive gland of indigenous and transplanted mussel Mytilus galloprovincialis in Venice Lagoon, Italy. Mar. Environ. Res. 46, 295-299, http://dx.doi.org/10.1016/S0141 1136(97)00117-7. 
Qiagen, 2009. OIAzol handbook: for efficient lysis of fatty tissues and all other types of tissue before RNA purification.

Qiagen, 2009. QuantiTect ${ }^{\circledR}$ reverse transcription handbook, 31.

Qiagen, 2011. QuantiFast ${ }^{\circledR}$ SYBR ${ }^{\circledR}$ Green PCR KIT Quick Start Protocol 3.

Regoli, F., Giuliani, M.E., 2013. Oxidative pathways of chemical toxicity and oxidative stress biomarkers in marine organisms. Mar. Environ. Res., http://dx. doi.org/10.1016/j.marenvres.2013.07.006.

Rola, R.C., Monteiro, M., da, C., Reis, S.R., da, S., Sandrini, J.Z., 2012. Molecular and biochemical biomarkers responses in the mussel Mytilus edulis collected from Southern Brazil coast. Mar. Pollut. Bull. 64, 766-771, http://dx.doi.org/10.1016 j.marpolbul.2012.01.004.

Schäfer, S., Köhler, A., 2009. Gonadal lesions of female sea urchin (Psammechinus miliaris) after exposure to the polycyclic aromatic hydrocarbon phenanthrene. Mar. Environ. Res. 68, 128-136, http://dx.doi.org/10.1016/j.marenvres.2009. 05.001.

Schlenk, D., Buhler, D.R., 1989. Xenobiotic biotransformation in the pacific oyster (Crassostrea gigas). Comp. Biochem. Physiol. Part C Comp. Pharmacol. 94, 469-475, http://dx.doi.org/10.1016/0742-8413(89)90100-X

Schlenk, D., 1998. Occurrence of flavin-containing monooxygenases in non-mammalian eukaryotic organisms. Comp. Biochem. Physiol. Part C Pharmacol. Toxicol. Endocrinol. 121, 185-195, http://dx.doi.org/10.1016/ S0742-8413(98)10060-9.

Schmittgen, T.D., Livak, K.J., 2008. Analyzing real-time PCR data by the comparative CT method. Nat. Protoc. 3, 1101-1108.

Siu, G.M., Draper, H.H., 1982. Metabolism of malonaldehyde in vivo and in vitro. Lipids $17,349-355$

Snyder, M., 2000. Cytochrome P450 enzymes in aquatic invertebrates: recent advances and future directions. Aquat. Toxicol. 48, 529-547, http://dx.doi.org 10.1016/S0166-445X(00)00085-0.

Tian, S., Pan, L., Sun, X., 2013. An investigation of endocrine disrupting effects and toxic mechanisms modulated by benzo[a]pyrene in female scallop Chlamys farreri. Aquat. Toxicol 144-145, 162-171, http://dx.doi.org/10.1016/j.aquatox. 2013.09.031.

Tian, S., Pan, L., Zhang, H., 2014. Identification of a CYP3A-like gene and CYPs mRNA expression modulation following exposure to benzo[a]pyrene in the bivalve mollusk Chlamys farreri. Mar. Environ. Res. 94, 7-15, http://dx.doi.org 10.1016/j.marenvres.2013.11.001.

Toledo-Silva, G., Siebert, M.N., Medeiros, I.D., Sincero, T.C.M., Moraes, M.O., Goldstone, J.V., Bainy, A.C.D., 2008. Cloning a new cytochrome P450 isoform (CYP356A1) from oyster Crassostrea gigas. Mar. Environ. Res. 66, 15-18, http:/ dx.doi.org/10.1016/j.marenvres.2008.02.010.

Travers, M.-A., Meistertzheim, A.-L., Cardinaud, M., Friedman, C.S., Huchette, S., Moraga, D., Paillard, C., 2010. Gene expression patterns of abalone Haliotis tuberculata, during successive infections by the pathogen Vibrio harveyi. J. Invertebr. Pathol. 105, 289-297, http://dx.doi.org/10.1016/j.jip.2010.08.001.

Trevisan, R., Arl, M., Sacchet, C.L., Engel, C.S., Danielli, N.M., Mello, D.F., Brocardo, C., Maris, A.F., Dafre, A.L., 2012. Antioxidant deficit in gills of Pacific oyster (Crassostrea gigas) exposed to chlorodinitrobenzene increases menadione toxicity. Aquat. Toxicol. 108, 85-93, http://dx.doi.org/10.1016/j.aquatox.2011. 09.023
Trevisan, R., Mello, D.F., Uliano-Silva, M., Delapedra, G., Arl, M., Dafre, A.L., 2014a. The biological importance of glutathione peroxidase and peroxiredoxin backup systems in bivalves during peroxide exposure. Mar. Environ. Res. 101, 81-90, http://dx.doi.org/10.1016/j.marenvres.2014.09.004.

Trevisan, R., Flesch, S., Mattos, J.J., Milani, M.R., Bainy, A.C.D., Dafre, A.L., 2014b. Zinc causes acute impairment of glutathione metabolism followed by coordinated antioxidant defenses amplification in gills of brown mussels Perna perna. Comp. Biochem. Physiol. C. Toxicol. Pharmacol. 159, 22-30, http://dx. doi.org/10.1016/j.cbpc.2013.09.007.

Trisciani, A., Perra, G., Caruso, T., Focardi, S., Corsi, I., 2012. Phase I and II biotransformation enzymes and polycyclic aromatic hydrocarbons in the Mediterranean mussel (Mytilus galloprovincialis Lamarck, 1819) collected in front of an oil refinery. Mar. Environ. Res. 79, 29-36, http://dx.doi.org/10.1016/ j.marenvres.2012.04.006.

Wang, C., You, Y., Wang, H., Liu, B., 2012. Genetic diversity of the sulfotransferase-like gene and one nonsynonymous SNP associated with growth traits of clam, Meretrix meretrix. Mol. Biol. Rep. 39, 1323-1331, http:// dx.doi.org/10.1007/s11033-011-0865-4.

Wei, L., Hu, Z., Dong, L., Zhao, W., 2015. A damage assessment model of oil spill accident combining historical data and satellite remote sensing information: a case study in Penglai 19-3 oil spill accident of China. Mar. Pollut. Bull. 91, 258-271, http://dx.doi.org/10.1016/j.marpolbul.2014.11.036.

Wendel, A., 1981. Detoxication and Drug Metabolism: Conjugation and Related Systems, Methods in Enzymology Methods in Enzymology. Elsevier, http://dx. doi.org/10.1016/S0076-6879(81)77046-0.

Wootton, E., Dyrynda, E., Pipe, R., Ratcliffe, N., 2003. Comparisons of PAH-induced immunomodulation in three bivalve molluscs. Aquat. Toxicol. 65, 13-25, http://dx.doi.org/10.1016/S0166-445X(03)00098-5.

Xiu, M., Pan, L., Jin, Q., Miao, J., 2015. Gender differences in detoxification metabolism of polycyclic aromatic hydrocarbon (chrysene) in scallop Chlamys farreri during the reproduction period. Comp. Biochem. Physiol. C Toxicol. Pharmacol. 170, 50-59, http://dx.doi.org/10.1016/j.cbpc.2015.02.003.

Zanette, J., Nunes, F.F., Medeiros, I.D., Siebert, M.N., Mattos, J.J., Lüchmann, K.H., Rodrigues de Melo, C.M., Bainy, A.C.D., 2008. Comparison of the antioxidant defense system in Crassostrea rhizophorae and Crassostrea gigas exposed to domestic sewage discharges. Mar. Environ. Res. 66, 196-198, http://dx.doi.org/ 10.1016/j.marenvres.2008.02.057.

Zanette, J., Jenny, M.J., Goldstone, J.V., Parente, T., Woodin, B.R., Bainy, A.C.D., Stegeman, J.J., 2013. Identification and expression of multiple CYP1-like and CYP3-like genes in the bivalve mollusk Mytilus edulis. Aquat. Toxicol., 101-112, http://dx.doi.org/10.1016/j.aquatox.2012.11.017 (128-129).

Zar, J.H., 1999. Biostatistical Analysis. Prentice-Hall, Englewood Cliffs.

Zhang, H., Pan, L., Tao, Y., 2014. Toxicity assessment of environmental pollutant phenanthrene in clam Venerupis philippinarum using oxidative stress biomarkers. Environ. Toxicol. Pharmacol. 37, 697-704, http://dx.doi.org/10. 1016/j.etap.2014.01.018. 